\title{
Edukasi Gizi Seimbang bagi Kader Posyandu pada Masa Pandemi Covid-19 sebagai Pencegahan Balita Stunting di Kabupaten Bogor
}

\author{
${ }^{1)}$ Tria Astika Endah Permatasari*, ${ }^{2)}$ Hirfa Turrahmi, ${ }^{3)}$ Illavina \\ ${ }^{1,3)}$ Program Studi Gizi, Fakultas Kedokteran dan Kesehatan Universitas Muhammadiyah Jakarta \\ ${ }^{2)}$ Program Studi Kebidanan, Fakultas Kedokteran dan Kesehatan Universitas Muhammadiyah Jakarta \\ Email: tria.astika@umj.ac.id
}

\begin{abstract}
ABSTRAK
Pandemi Covid-19 menyebabkan risiko peningakatan prevalensi stunting pada balita. Salah satu upaya yang dapat dilakukan untuk mencegah terjadinya stunting melalui edukasi yang terus menerus. Tujuan dari kegiatan pengabdian kepada masyarakat (PKM) ini adalah untuk meningkatkan pengetahuan dan sikap kader posyandu mengenai pesan gizi seimbang yang diberikan secara berseri melalui media sosial di wilayah Kecamatan Caringin, Kabupaten Bogor. Metode yang digunakan dalam kegiatan PKM ini adalah melalui media sosial (whatsapp group) dengan cara memberikan pesan secara berseri sesuai dengan 4 (empat) pilar gizi seimbang yang mencakup 1) konsumsi makanan beraneka ragam, 2) Perilaku Hidup Bersh dan Sehat (PHBS), 3) pemantauan berat badan, dan 4) aktivitas fisik. Pesan diberikan kepada 42 kader yang berasal dari Desa Tangkil dan Desa Pasir Buncir, masing-masing 21 orang kader untuk setiap desa yang dilakukan selama Bulan Juli-Agustus tahun 2020. Hasil edukasi menunjukkan bahwa terjadi peningkatan rata-rata skor pengetahuan mengenai gizi seimbang terkait pencegahan terjadinya stunting pada balita dari 77,52 $\pm 10,82$ SD saat pre-test menjadi $82,19 \pm 9,93 \mathrm{SD}$ saat posttest. Selain itu, rata-rata skor sikap juga meningkat dari 40,21 $\pm 6,67$ SD menjadi 44,48 $\pm 5,44$ SD. Kader posyandu diharapkan dapat menjadi agen perubahan perilaku pencegahan stunting melalui edukasi kepada orang tua balita untuk mencegah terjadinya stunting di masa pandemi Covid-19.
\end{abstract}

Kata kunci: balita, stunting, kader posyandu, gizi seimbang, pandemi covid-19

\section{ABSTRACT}

The Covid-19 pandemic causes an increased risk of stunting prevalence in children under five. One of the efforts that can be made to prevent stunting is through continuous education. The purpose of this community service activity (PKM) is to increase the knowledge and attitudes of posyandu cadres regarding the message of balanced nutrition given in series through social media in the Caringin District, Bogor Regency. The method used in this PKM activity is through social media (Whatsapp group) by giving messages in a series according to the 4 (four) pillars of balanced nutrition which includes 1) consumption of a variety of foods, 2) Behavior of Clean and Healthy Living (PHBS), 3) monitoring of body weight, 4) physical activity. Messages were given to 42 cadres from Tangkil Village and Pasir Buncir Village, every 21 cadres conducted during July-August 2020. PKM results show that there is an increase in the average knowledge score of 77.52 $\pm 10,82 \mathrm{SD}$ (before) became $82.19 \pm 9.93 \mathrm{SD}$. In addition, the average attitude score increased from $40.21 \pm 6.67 \mathrm{SD}$ to $44.48 \pm$ 5.44 SD. Posyandu cadres are expected to become agents of behavior change in preventing stunting by educating parents of toddlers to prevent stunting during the Covid-19 pandemic.

Keywords: children under five years, stunting, posyandu cadres, balanced diet, Covid-19 pandemic 


\section{PENDAHULUAN}

Pola konsumsi pangan yang tidak tepat selama periode pandemi covid-19 berdampak terhadap munculnya berbagai malnutrisi. Kondisi ini terjadi akibat ketidakaseimbangan asupan gizi baik kekurangan maupun kelebihan gizi yang dapat meningkatkan risiko terjadinya berbagai penyakit dan meningkatkan risiko terhadap kematian (World Food Programme, 2020). World Health Organization (WHO) bahkan telah mendeklarasikan penyakit yang disebabkan oleh Severe Acute Respiratory Syndrome Coronavirus-2 (SARSCoV-2) tersebut sebagai 'Darurat Kesehatan Masyarakat'(World Health Organization, 2020). Provinsi dengan jumlah kasus positif covid-19 dan CFR tertinggi yaitu meliputi Provinsi DKI Jakarta, Provinsi Jawa Timur, dan Provinsi Jawa Barat (Kementerian Kesehatan Republik Indonesia, 2020). Tingginya peningkatan kasus Covid-19 pada anak menyebakan riskiko terjadinya kekurangan gizi terutama stunting, bahkan menyebabkan kematian. Ketidakseimbangan asupan gizi dapat meningkatkan fatalitas dari infeksi covid-19. Sebaliknya, pasien yang terpapar covid-19 berisiko tinggi mengalami malnutrisi. Terdapat hubungan sinergis antara kekurangan gizi dan infeksi yang dapat meningkat dalam kondisi pandemi Covid-19.

Laporan dari Gugus Penanganan Covid-19 di Indonesia menyebutkan bahwa kasus pasien terkonfirmasi positif Covid-19 pada anak semakin meningkat bahkan menduduki peringkat pertama di Asia Tenggara (Childs, Calder, Miles, 2019). Kondisi seperti ini, secara langsung dapat menyebabkan tingginya prevalensi balita stunting, dan begitupun sebaliknya dimana jumlah balita stunting yang tinggi meningkatkan risiko paparan dan fatalitas dari covid-19 pada anak. Provinsi Jawa Barat (31\%) dengan penyumbang tertinggi adalah di Kabupaten Bogor (28\%). Kantong stunting di kabupaten ini terdapat di Kecamatan Caringin (Dinkes Jawa Barat, 2015) (Kementerian Kesehatan Republik Indonesia, 2018). Hasil penelitian pendahuluan menunjukkan bahwa cakupan balita stunting di Kecamatan Caringin yaitu sebanyak 30\%. Kabupaten Bogor juga selain memiliki prevalensi balita stunting yang tinggu, juga termasuk dalam zona tinggi kasus Covid-19 nya. Salah satu upaya yang dapat dilakukan dalam mencegah peningkatan jumlah kasus Covid-19 dan terjadinya balita stunting pada anak adalah melalui upaya edukasi gizi seimbang, karena terdapat hubungan timbal balik antara gizi dan infeksi.

Beberapa desa yang merupakan lokus stunting di wilayah ini adalah Desa Pasir Buncir dan Desa Tangkil. Kedua tersebut, berdasarkan hasil penelitian sebelumnya memiliki karakteristik sosiodemografi yaitu sosial ekonomi rendah, pendidikan, kondisi sanitasi dan hygiene yang kurang baik, serta pengetahuan tentang gizi yang rendah. Begitupun kader posyandu dikedua desa tersebut, seluruhnya merupakan ibu rumah tangga yang secara penuh waktu kerjanya digunakan untuk menjadi kader. Sebagian besar kader memiliki tingkat pendidikan yang rendah (70\%). Pengetahuan keluarga maupun kader mengenai gizi masih rendah.

Stunting berdampak terhadap kematian pada balita. Gambaran di wilayah lokasi penelitian secara umum juga menunjukkan bahwa berdasarkan data hasil SDKI Tahun 2012 menunjukkan AKB di Provinsi Jawa Barat sebesar 30 per 1000 Kelahiran Hidup (profil Kesehatan Provinsi Jawa Barat Tahun 2014. AKB di Kabupaten Bogor dari Tahun 2012 sampai dengan Tahun 2016 angka pencapaiannya tetap yaitu sebesar 41,82 per 1000 kelahiran hidup (BPS). Penurunan prevalensi stunting menjadi priotitas Sustainable Development Goals (SDG's) di Indonesia hingga tahun 2030 untuk menurunkan sebanyak 40\% dari jumlah balita stunting (Kementerian Kesehatan Republik Indonesia, 2018). Secara langsung stunting disebabkan oleh asupan makanan dan penyakit infeksi yang ditentukan oleh pola asuh ibu (Huicho, et al. 2017; Bogale, Bala, Tadese, 2018; , De Vlieger, Riley, Miller, et al, 2018). Penurunan prevalensi stunting menjadi prioritas program kerja lintas 
sektor dihampir seluruh wilayah di Indonesia, termasuk di Kabupaten Bogor (Dinas Kesehatan Provinsi Jawa Barat, 2015).

Mitra pengabdian kepada Masyarakat, yaitu Desa Tangkil dan Desa Pasir Buncir di Kecamatan Caringin memerlukan peran dari berbagai pihak di masyasrakat termasuk dari akademisi untuk meningkatkan pengetahuan dan kesadaran keluarga, melalui peran kader sebagai penggerak utama dan terdepan dalam perubahan pengetahuan, sikap, dan perilaku terkait gizi yang bersifat permanen, sehingga dapat menurunkan prevalensi stunting di wilayah tersebut. Dengan demikian, berdasrkan masalah prioritas di wilayah tersebut, dimana prevalensi yang tinggi terutama di masa pandemic Covid-19 yang belum menunjukkan penurunan secara indikator epdiemiologi, maka dengan ini diperlukan upaya edukasi gizi sebagai salah satu pesan yang harus diberikan kepada masyarakat, melalui kader posyandu. Tujuan kegiatan pengabdian kepada masyarakat ini untuk meningkatkan pengetahuan dan sikap kader posyandu mengenai pesan gizi seimbang yang diberikan secara berseri melalui media sosial di wilayah Kecamatan Caringin, Kabupaten Bogor.

\section{METODE}

Pengabdian kepada masyarakat ini dilakukan melalui pendekatan pemberdayaan masyarakat dimana secara teknis operasional yaitu dengan memberikan edukasi gizi seimbang kepada kader posyandu untuk mengoptimalkan perannya sebagai agen dalam mempromosikan gizi dan kesehatan di wilayah yang menjadi lokus stunting di Kabupaten Bogor. Edukasi diberikan melalui media sosial (whatsapp group) dengan cara memberikan pesan secara berseri sesuai dengan 4 (empat) pilar gizi seimbang yang mencakup 1) konsumsi makanan beraneka ragam, 2) Perilaku Hidup Bersh dan Sehat (PHBS), 3) pemantauan berat badan, 4) aktivitas fisik. Pesan diberikan kepada 42 kader yang berasal dari Desa Tangkil dan Desa Pasir Buncir, masing-masing 21 orang kader yang dilakukan selama Bulan Juli-Agustus tahun 2020. Kuesioner diisi melalui google forms. Materi edukasi yang disampaikan dalam edukasi ini bersumber dari materi yang dikeluarkan oleh Kemenkes RI tahun 2020 tentang Pedoman Gizi Seimbang pada Masa Pandemi Covid-19 (Kementerian Kesehatan Republik Indonesia, 2020), seperti contoh berikut (Gambar 1 dan 2).

Data dianalisis secara univariat untuk mengetahui gambaran karakteristik sosiodemografi, serta pengetahuan dan sikap kader posyandu mengenai gizi seimbang. Peningkatan skor pengetahuan dan sikap kader posyandu antara sebelum dan setelah diberikan edukasi gizi seimbang melalui pesan berseri di media sosial, dianalisis menggunakan uji t-dependen dengan tingkat kemaknaan 5\%.
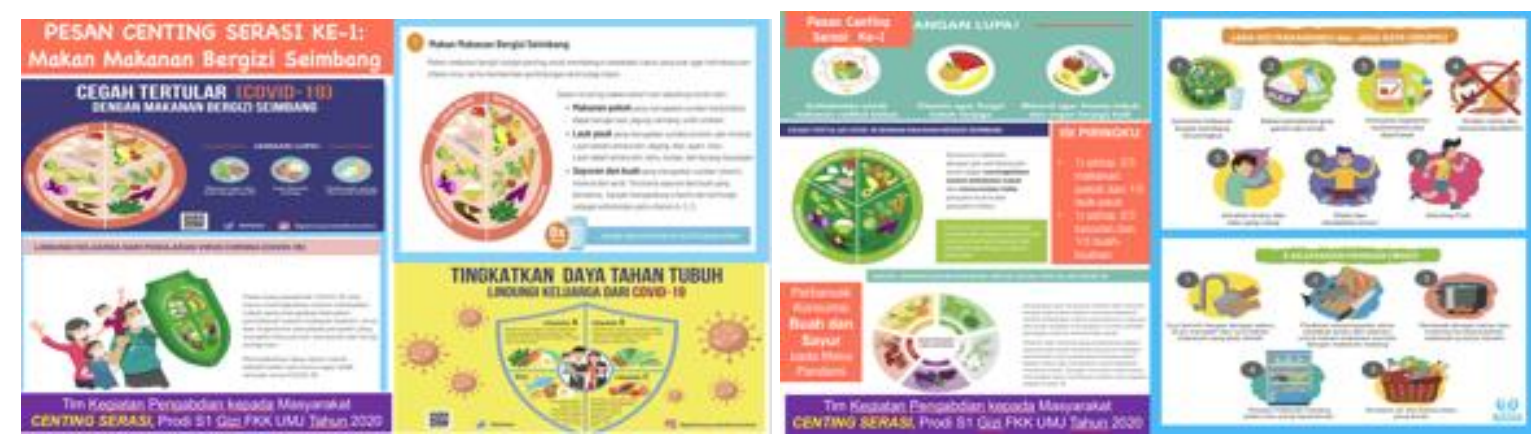

Gambar 1. Pesan Gizi Seimbang mengenai Konsumsi Aneka Ragam Makanan

Sumber : Pedoman Gizi Seimbang pada Masa Pandemi Covid-19

(Kementerian Kesehatan Republik Indonesia, 2020) 


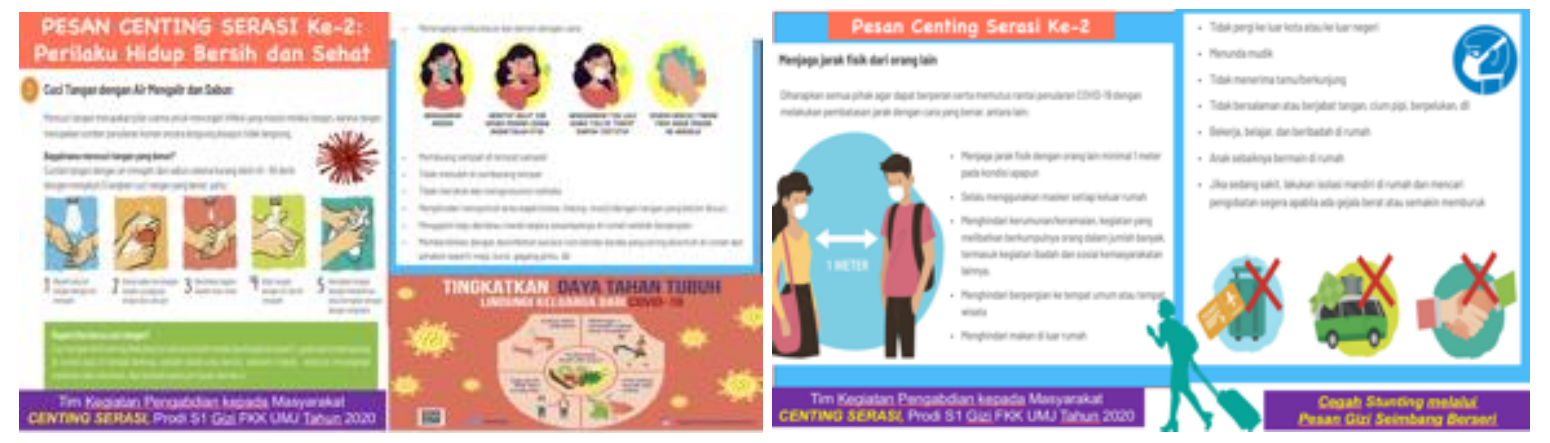

Gambar 2. Pesan Gizi Seimbang mengenai Perilaku Hidup Bersih dan Sehat

(Kementerian Kesehatan Republik Indonesia, 2020)

\section{HASIL DAN PEMBAHASAN}

\section{Gambaran Karakteristik Sosiodemografi Kader Posyandu}

Berdasarkan Tabel 1, dapat diketahui bahwa usia kader bervariasi yaitu mencakup rentang usia 21 hingga 55 tahun. Sebagian besar ibu kader berpendidikan rendah yaitu sebanyak 33,3\% tamat SD dan 35, 7\% tamat SMP. Hampir seluruh kader merupakan ibu rumah tangga yaitu sebanyak $92,9 \%$. Hanya terdapat $4,8 \%$ ibu adalah Guru TK dan 2,4\% masih berstatus sebagai mahasiswa. Motivasi untuk menjadi kader adalah untuk membantu meningkatkan derajat kesehatan masyarakat. Sebagian besar kader bertugas antara 1-3 tahun yaiu sebanyak 45,2\% kurang dari 1 tahun dan sebanyak 35,7\% sebanyak 35,7\%. Lebih dari separuh suami dari kader posyandu berpendidikan rendah yaitu sebanyak 33,3\% tamat SD dan $23,8 \%$ tamat SMP. Separuh dari suami kader posyandu bekerja sebagai buruh harian yaitu sebanyak $50,0 \%$. Sedangkan persentasi tertinggi lainnya adalah bekerja sebagai karyawan swasta yaitu 28,6\%. Tingkat pendapatan keluarga kader posyandu yang paling banyak pada kisaran Rp.1.000.000 - Rp. 2.000.000 yaitu sebanyak 35,7\%. Masih terdapat pendapatan keluarga kader posyandu dibawah Rp.1.000.000 sebanyak 28,6\%. 

SYIFA

Tabel 1. Karakteristik Sosiodemografi Kader Posyandu

\begin{tabular}{|c|c|c|}
\hline Karakteristik Kader & Jumlah (n) & Persentase (\%) \\
\hline \multicolumn{3}{|l|}{ Usia } \\
\hline \multicolumn{3}{|l|}{ Minimum 21 Tahun } \\
\hline \multicolumn{3}{|l|}{ Maximum 55 Tahun } \\
\hline \multicolumn{3}{|l|}{ Mean 35,02 } \\
\hline \multicolumn{3}{|l|}{ Standar Deviasi 6,712 } \\
\hline \multicolumn{3}{|l|}{ Tingkat Pendidikan } \\
\hline SD & 14 & 33,3 \\
\hline SMP & 15 & 35,7 \\
\hline SMA & 12 & 28,6 \\
\hline $\mathrm{S} 1$ & 1 & 2,4 \\
\hline \multicolumn{3}{|l|}{ Pekerjaan } \\
\hline IRT & 39 & 92,9 \\
\hline Guru TK & 2 & 4,8 \\
\hline Kuliah & 1 & 2,4 \\
\hline \multicolumn{3}{|l|}{ Motivasi } \\
\hline Pengalaman dan mengenal warga & 1 & 2,4 \\
\hline Membantu meningkatkan derajat kesmas & 37 & 88,1 \\
\hline Menjalankan perintah aparat pemerintah & 3 & 7,1 \\
\hline Membantu kesehatan lingkungan & 1 & 2,4 \\
\hline \multicolumn{3}{|l|}{ Lama Menjadi Kader } \\
\hline$<1$ Tahun & 19 & 45,2 \\
\hline 1-3 Tahun & 15 & 35,7 \\
\hline$>3-5$ Tahun & 3 & 7,1 \\
\hline$>$ 5-10 Tahun & 2 & 4,8 \\
\hline$>10$ Tahun & 3 & 7,1 \\
\hline \multicolumn{3}{|l|}{ Pendidikan Suami } \\
\hline $\mathrm{SD}$ & 14 & 33,3 \\
\hline SMP & 10 & 23,8 \\
\hline SMA & 15 & 35,7 \\
\hline Diploma & 2 & 4,8 \\
\hline $\mathrm{S} 1$ & 1 & 2,4 \\
\hline \multicolumn{3}{|l|}{ Pekerjaan Suami } \\
\hline Tidak bekerja & 1 & 2,4 \\
\hline Buruh & 21 & 50,0 \\
\hline Buruh serabutan & 1 & 2,4 \\
\hline Wiraswasta & 4 & 9,5 \\
\hline Karyawan swasta & 12 & 28,6 \\
\hline PNS & 3 & 7,1 \\
\hline \multicolumn{3}{|l|}{ Tingkat Pendapatan Keluarga } \\
\hline$<$ Rp. 1.000 .000 & 12 & 28,6 \\
\hline Rp.1.000.000 - Rp.2.000.000 & 15 & 35,7 \\
\hline > Rp.2.000.000 - Rp.3.000.000 & 8 & 19,0 \\
\hline > Rp.3.000.000 - Rp.4.000.000 & 3 & 7,1 \\
\hline > Rp.4.000.000 - Rp.5.000.000 & 4 & 9,5 \\
\hline
\end{tabular}




\section{Pengaruh Edukasi Gizi Seimbang terhadap Peningkatan Sikap dan Pengetahuan Kader Posyandu}

Pengetahuan kader posyandu mengalami peningkatan dari sebelum dan setelah dilakukan edukasi mengalami peningkatan secara bermakna (nilai $\mathrm{p}=0,000$ ). Nilai rata-rata pengetahuan saat awal adalah 77,52 $\pm 10,82$ dan saat akhir setelah edukasi adalah 82,19 $\pm 9,93$. Begitu pula sikap kader posyandu mengalami peningkatan dari sebelum dan setelah dilakukan edukasi mengalami peningkatan secara bermakna (nilai $\mathrm{p}=0,000$ ). Nilai rata-rata pengetahuan saat awal adalah 40,21 $\pm 6,67$ SD dan saat akhir setelah edukasi adalah 44,48 $\pm 5,44$ SD (Tabel 2).

Tabel 2. Gambaran Pengetahuan dan Sikap Kader Posyandu

\begin{tabular}{lccccc}
\hline \multicolumn{1}{c}{ Variabel } & Minimum & Maximum & Mean & Standar Deviasi & Nilai p \\
\hline Pengetahuan & 52 & 92 & 77,52 & 10,82 & 0,000 \\
\hline Sebelum Eduksi & 60 & 96 & 82,19 & 9,93 & \\
Setelah Edukasi & 50 & 50 & 40,21 & 6,67 & 0,000 \\
\hline Sikap & 18 & 50 & 44,48 & 5,44 & \\
Sebelum Edukasi & 30 & & & & \\
Setelah Edukasi & & & & & \\
\hline
\end{tabular}

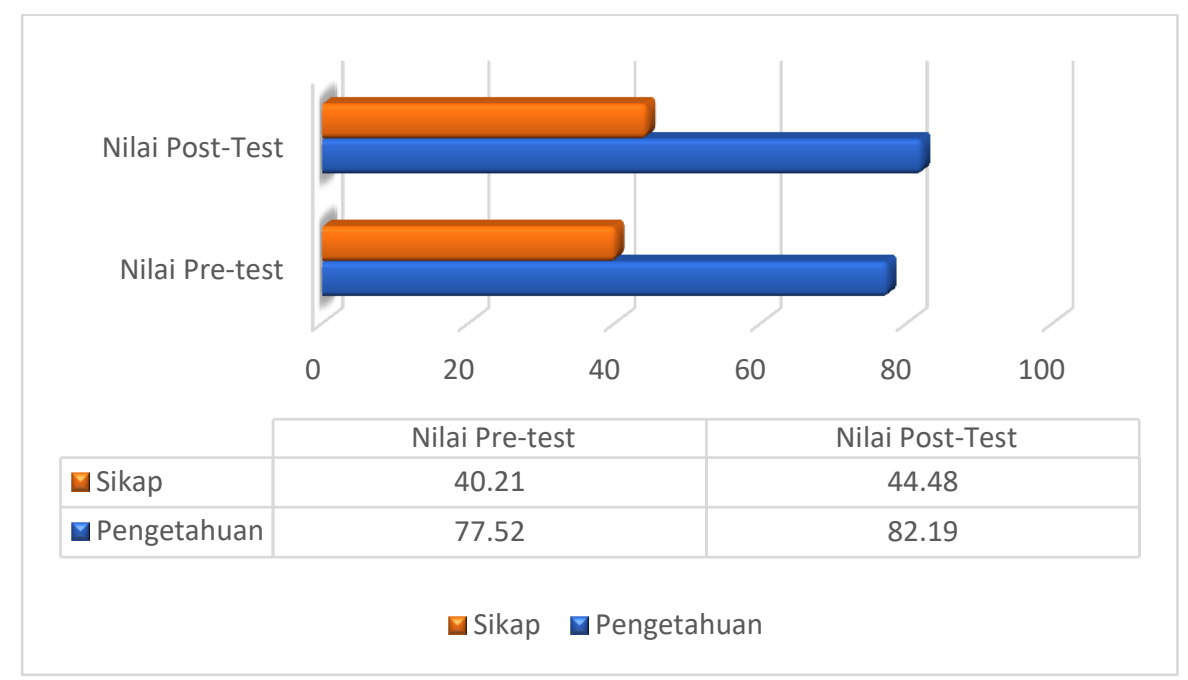

Gambar 3. Peningkatan Skor Pengetahuan dan Sikap Kader Posyandu 
Edukasi Centing Serasi telah menunjukkan manfaat yang positif terhadap peningkatan pengetahuan dan sikap dari kader mengenai penerapan gizi. Seimbang pada masa pandemic Covid-19. Edukasi gizi dan kesehatan reproduksi dapat meningkatkan kecermatan ibu dalam implementasi praktik gizi seimbang, pola asuh serta peningkatan kesehatan reproduksi melalui pemilihan metode kontrasepsi yang tepat terutama dalam periode 1000 Hari Pertama Kehidupan (1000 HPK) (Markulis dan Strang, 2015). Berbagai model intervensi untuk mencegah terjadinya stunting pada balita sudah banyak dilakukan. Namun prevalensi stunting belum menurun secara signifikan. Hal ini dapat disebabkan umumnya model yang digunakan baru menargetkan pada perubahan pengetahuan dan sikap. Salah satu model yang digunakan adalah Emotional Demonstration (Emo Demo), yaitu metode edukasi masyarakat melalui pendekatan baru yang mengacu pada teori Behavior Centered Design (BCD) (Amareta dan Ardianto, 2017). Edukasi yang telah dilakukan pada kegiatan pengabdian kepada maysrakat dalam bentuk pesan berseri juga dapat dilakukan secara efektif dengan adanya komitmen dari kader posyandu untuk melaksanakan seluruh kegiatan dan memenuhi tata tertib yang ditetapkan selama proses edukasi berjalan.

Metode edukasi dapat dilakukan melalui berbagai cara baik diberikan oleh kader mapun peer group. Metode edukasi melalui peer group juga banyak dilakukan karena memberikan pengaruh signifikan dalam meningkatkan pengetahuan, sikap, perilaku yang dapat meningkatkan status kesehatan pada berbagai kelompok di masyarakat (Komalasari, Permatasari, Supriyatna, 2020; Permatasari, 2017). Seiring dengan perkembangan teknologi informasi dan tuntutan kondisi pandemi Covid-19 yang membutuhkan edukasi menggunakan berbagai aplikasi digital yang memudahkan penyampaian pesan kepada kelompok sasaran. Beberapa contoh aplikasi yang telah dikembangkan dalam memberikan edukasi gizi dan kesehatan adalah aplikasi 'SIMENCAR' yang digunakan untuk memberikan edukasi mengenai kesehatan reproduksi yaitu diberikan pada remaja putri pada masa prapubertas sebagai persiapan periode menarche (Risidiana, Purwati, Permatasari, 2020). Selain itu terdapat aplikasi lainnya untuk melakukan skrining terhadap adanya malnutrisi pada balita sekaligus memberikan edukasi gizi melalui aplikasi yang nerupakan modifikasi dari STRONGkids (Screening Tool Risk on Nutritional and Growth). Aplikasi tersebut memiliki tingkat sensitivitas sebesar $83,3 \%$ dan secara signfikan dapat meningkatkan pengetahuan gizi ibu termasuk pengetahuan mengenai pemberian makan pada balita (Maharani, Purwati, Permatasari, 2020).

Edukasi gizi sebagai upaya pencegahan stunting pada balita merupakan salah satu tujuan dari pembangunan kesehatan yang berkelanjutan dan tertuang dalam Sustainable Development Goals (SDG's) (WHO, 2018). Upaya pencegahan stunting secara efektif dapat dilakukan pada periode 1000 Hari Pertama Kehidupan, terutama pada saat kehamilan (Mistry, Hosain, Arora, 2019; Dhaded, et al, 2020). Selain itu praktik pemberian makan dengan gizi seimbang pada balita sangat berkontribusi terhadap pertumbuhan dan perkembangan optimal pada balita (Millward, 2017; Uwiringiyimana, et al, 2019). Upaya edukasi gizi sebagai pencegahan terjadinya stunting pada balita menjadi langkah strategis. Hal ini disebabkan stunting sebagai indikator kegagalan pertunbuhan memberikan dampak terhadap terjadinya gangguan fungsional, termasuk rendahnya perkembangan kognitif dan fisik, gangguan metabolisme yang dapat meningkatkan risiko terjadinya penyakit degenerative, serta perkembangan sosio emosional balita (Alam et al, 2020; Sanou et al, 2018; Rolfe, et al, 2018). Oleh karena itu diperlukan upaya pencegahan yaitu salah satunya melalui edukasi gizi bagi kader posyandu sebagai agen promosi kesehatan yang secara langsung dapat berinteraksi dengan keluarga dan masyrakat, sehingga efektif dalam menurunkan prevalensi stunting. 
Stunting pada balita disebabkan oleh banyak faktor, terutama kekurangan asupan gizi sejak periode 1000 Hari Pertama Kehidupan (1000 HPK). Rendahnya asupan gizi saat perode kehamilan, tidak diberikannya ASI eksklusif, pemberian Makanan Pendamping ASI (MPASI) yang terlalu dini, serta terpaparnya balita oleh penyakit infeksi merupakan faktor-faktor utama penyebab stunting (Millward, 2017; Uwiringiyimana, et al, 2019). Pemenuhan gizi pada periode kritis tersebut dipengaruhi oleh pengetahuan ibu tentang gizi. Selain itu keberhasilan pemberian Inisasi Menyusu Dini (IMD) yang dilanjtukan dengan pemberian ASI eksklusif sebagai tahap pemenuhan asupan pertama bagi bayi dalam 6 (enam) bulan pertama kehidupan ditentukan oleh intensi ibu sejak periode kehamilan (Permatasari dan Syafruddin, 2016; Permatasari, et al, 2016; Permatasari, et al, 2018). Pemberian MP-ASI yang tinggi gula terutama diberikan pada saat sebelum bayi berusia 6 (enam) bulan seperti kental manis juga dapat menyebabkan rendahnya status gizi pada balita (Permatasari dan Chadirin, 2020). Selanjutnya status gizi yang buruk meningkatkan terjadinya risiko berbagai penyakit infeksi seperti tuberkulosis yang dapat menyebabkan kematian (Erni Rita, et al, 2020).

Berbabagi upaya telah dilakukan dalam menurunkan stunting baik berupa intervensi gizi sentsitif melalui lintas sektor dan intervensi gizi spesifik dalam meningkatkan asupan makan balita. Salah satu upaya yang mengoptimalkan peran kader dalam menurunkan prevalensi stunting pada balita dapat dilakukan adalah melalui penguatan kapasitas kader. Hal ini dapat dilihat dari adanya Gerakan 'Aisyiyah Sehat (GRASS) dalam meningkatkan penguatan kader sebagai upaya pemberdayaan masyarakat, dimana salah satu tujuannya adalah untuk menurunkan prevalensi stunting di Provinsi Kalimantan Tengah. Kegiatan pemberdayaan masyarakat tersebut juga telah dilakukan di beberapa provinsi lainnya (Permatasari, Chairunnisa, dan Herlina, 2019).

\section{KESIMPULAN DAN SARAN}

Edukasi 'Centing Serasi' (Cegah Stunting melalui Pesan Gizi Seimbang secara Berseri) terbukti dapat meningkatkan pengetahuan dan sikap kader Posyansdu di wilayah Kecamatan Caringin, Kabupaten Bogor. Oleh karena itu rekomendasi yang dapat diberikan dari hasil kegiatan Pengabdian kepada Masyarakat ini adalah:

1. Melakukan edukasi Cemting Serasi secara luas, dilakukan terhadap kader lainnya di wilayah yang menjadi lokus stunting;

2. Melakukan tindak lanjut kegiatan ini dengan meneruskan edukasi kepada sasaran utama yaitu ibu hamil, ibu balita, dan elemen keluarga atau pihak terdekat lainnya yang berperan dalam pertumbuhan dan perkembangan balita

\section{UCAPAN TERIMA KASIH}

Terima kasih kami sampaikan kepada Lembaga Penelitian dan Pengabdian kepada Masyarakat Universitas Muhammadiyah Jakarta dan Fakultas Kedokteran dan Kesehatan Universitas Muhammadiyah Jakarta yang telah memfasilitasi pelaksanaan dan pendanaan kegiatan Pengabdian kepada Masyarakat ini. Terima kasih pula kepada seluruh kader posyandu yang telah terlibat secara aktif dalam kegiata pengabdian kepada masyarakat ini. Kami juga ucapkan terima kasih kepada kepala desa dan tenaga kesehatan di wilayah Kecamatan Caringin, Kabupaten Bogor yang sangat baik bekerjasama dalam kegiatan ini. 


\section{DAFTAR PUSTAKA}

Alam, MA., et al. (2020). Impact of early-onset persistent stunting on cognitive development at 5 years of age: Results from a multi-country cohort study. PLoS One: 15(1):1-16

Amareta DI dan Ardianto ET. (2017). Penyuluhan Kesehatan dengan Metode Emo Demo Efektif Meningkatkan Praktik CTPS di MI Al-Badri Kalisat Kabupaten Jember. Seminar Nasional Hasil Penelitian 2017, ISBN : 978-602-14917-5-1.

Bogale TY, Bala ET, Tadese M. (2018). Prevalence and associated factors for stunting among 6-12 years old school age children from rural community of Humbo district, Southern Ethiopia. BMC Public Health (2018) 18:653 https://doi.org/10.1186/s12889-018-5561-z

Childs CE, Calder PE, Miles EA. (2019). Diet and Immune Function. Nutrients, 11, 1933; 19. doi:10.3390/nu11081933. www.mdpi.com/journal/nutrients

De Vlieger N, Riley N, Miller A, et al. (2018). Nutrition education in the Australian New South Wales primary school curriculum: An exploration of time allocation, translation and attitudes in a sample of teachers. Health Promot J Austral. 2019;30:94-101.

Dhaded, et al. (2020). Preconception nutrition intervention improved birth length and reduced stunting and wasting in newborns in South Asia: The Women First Randomized Controlled Trial. PLoS One [Internet]. 2020;15(1):1-15. http://dx.doi.org/10.1371/journal.pone.0218960

Dinas Kesehatan Provinsi Jawa Barat. (2015). Profil Kesehatan Provinsi Jawa Barat Tahun 2015.

Erni Rita, Saputri IN, Widakdo G, Permatasari TAE, Kurniaty I. (2020). Riwayat kontak dan status gizi buruk dapat meningkatkan kejadian tuberkulosis pada anak. Jurnal Kesehatan Masyarakat Khatulistiwa; 7(1): 20-29. DOI: http://dx.doi.org/10.29406/jkmk.v7i1.1988. http://openjurnal.unmuhpnk.ac.id/index.php/JKMK/article/view/1988

Huicho L., et al. (2017). Factors behind the success story of under-five stunting in Peru: a district ecological multilevel analysis. BMC Pediatrics (2017) 17:29 DOI 10.1186/s12887-017-0790-3.

Kementerian Kesehatan Republik Indonesia. (2020). Situasi terkini perkembangan Coronavirus Disease (Covid-19) 6 Mei 2020. https://covid19.kemkes.go.id/situasiinfeksi-emerging/info-corona-virus/situasi-terkini-perkembangan-coronavirus-diseasecovid-19-6-mei-2020/\#.XrTHgi2B104

Kementerian Kesehatan Republik Indonesia. (2020). Pedoman Gizi Seimbang pada Masa Pandemi Covid-19. Jakarta

Kementerian Kesehatan Repubik Indonesia. (2018). Hasil Utama Riset Kesehatan Dasar 2018. $\quad$ http://kesmas.kemkes.go.id/assets/upload/dir 519d41d8cd98f00/files/Hasilriskesdas-2018_1274.pdf.

Kementerian Kesehatan Republik Indonesia. (2018). Situasi Balita Pendek di Indonesia. Buletin Jendela Data dan Informasi Kesehatan. ISSN: 2088-270X

Komalasari T, Permatasari TAE, Supriyatna N. (2020). Pengaruh Edukasi dengan Metode Peer Group terhadap Perubahan Pengetahuan, Sikap, dan Tekanan Darah pada Lansia di UPTD Puskesmas Sukajaji Kabupaten Majalengka. Syntax Literate: Jurnal Ilmiah Indonesia. Vol 5(5); 184-196. DOI: http://dx.doi.org/10.36418/syntaxliterate.v5i5.1114. $\quad$ http://www.jurnal.syntaxliterate.co.id/index.php/syntaxliterate/article/view/1114 
Maharani R, Purwati NY, Permatasari, TAE. (2020). Screening for malnutrition and the effect of education using the STRONGkids application on increasing mother's knowledge and children's eating behaviour. The International Journal of Social Sciences World; 2(2): 144-152. DOI: https://doi.org/10.5281/zenodo.4090781. https://www.growingscholar.org/journal/index.php/TIJOSSW/article/view/71

Markulis P dan Strang D. 2015. Emotional Intelligence: A Demonstration. Developments in Business Simulation and Experiential Learning, volume 42, 2015, p.184.

Millward DJ. (2017) Nutrition, infection and stunting: The roles of deficiencies of individual nutrients and foods, and of inflammation, as determinants of reduced linear growth of children. Nutr Res Rev. : 30(1):50-72

Mistry SK, Hossain MB, Arora A. (2019). Maternal nutrition counselling is associated with reduced stunting prevalence and improved feeding practices in early childhood: A postprogram comparison study. Nutr J;18(1):1-9.

Permatasari TAE, Sayfruddin A. (2016). Early initiation of breastfeeding related to exclusive breastfeeding and breastfeeding duration in rural and urban areas in Subang, West Java, Indonesia. J Health Res; 30(5): 337-45. DOI: 10.14456/jhr.2016.46. https://he01.tcithaijo.org/index.php/jhealthres/article/view/77866

Permatasari TAE, Sartika RAD, Achadi EL, Purwono U, Irawati A, et al. (2016). Does breastfeeding intention among pregnant mothers associated with early initiation of breastfeeding?. Jurnal Kesehatan Reproduksi; 7(3): 169-184. DOI: 10.22435/kespro.v7i3.6278.169-184. http://ejournal.litbang.kemkes.go.id/index.php/kespro/article/view/6278

Permatasari TAE. (2017). Peningkatan pengetahuan dan perilaku gizi seimbang menggunakan peer education. Kes Mas: Jurnal Fakultas Kesehatan Masyarakat. 11(2):114-120.

DOI: http://dx.doi.org/10.12928/kesmas.v11i2.5575. http://journal.uad.ac.id/index.php/KesMas/article/view/5575/pdf_107

Permatasari TAE, Sartika RAD, Achadi EL, Purwono U, Irawati A. (2018). Exclusive breastfeeding intention among pregnant women. Kesmas: National Public Health Journal; $\quad$ 12(3):134-141.

DOI:10.21109/kesmas.v12i3.1446. http://journal.fkm.ui.ac.id/index.php/kesmas/article/view/1446.

Permatasari TAE, Chadirin Y. (2020). Sweetened condensed consumption of more than 1 glass per day has an impact on underweight among children under age five. Proceedings 4th International Symposium on Health Research (ISHR 2019): Advances in Health Sciences research (ISHR 2019); Vol 22:615-619. DOI: https://doi.org/10.2991/ahsr.k.200215.120. press.com/proceedings/ishr-19/125935054.

https://www.atlantis-

Permatasari TAE, Chairunnisa, Herlina L. (2019). Penguatan kapasitas kader melalui gerakan 'Aisyiyah Sehat (GRASS) sebagai upaya pencegahan penyakit tidak menular dan stunting, serta peningkatan kesehatan ibu dan anak di Provinsi Kalimantan Tengah. Prosiding Seminar Nasional Pengabdian Masyarakat LPPM UMJ: 2019:1-5 https://jurnal.umj.ac.id/index.php/semnaskat/article/viewFile/5429/3639.

Risdiana R, Purwati NH, Permatasari TAE. (2020). The effectiveness of menarche education via the Simencar Application. The International Journal of Social Sciences World: 2(2):153-160. DOI: $\quad$ https://doi.org/10.5281/zenodo.4115896. https://www.growingscholar.org/journal/index.php/TIJOSSW/article/view/75

Rolfe, E.D.L., et al (2018). Associations of stunting in early childhood with cardiometabolic risk factors in adulthood;1-13. 

SYIFA

Sanou, A.S., et al. (2020). Association between stunting and neuro-psychological outcomes among children in Burkina Faso, West Africa. Child Adolesc Psychiatry Ment Health [Internet]. 2018;12(1):1-10. Tersedia pada: https://doi.org/10.1186/s13034-018-0236-1

Uwiringiyimana V, et al. (2019). Predictors of stunting with particular focus on complementary feeding practices: A cross-sectional study in the northern province of Rwanda. Nutrition: 60:11-8.

World Food Programme. 2020. Covid-19: potential impact o the world's poorest people. https://www.wfp.org/publications/covid-19-potential-impact-worlds-poorest-people

World Health Organization (WHO). (2018). Reducing stunting in children. Equity considerations for achieving the Global Nutrition Targets 2025 [Internet]. Tersedia pada: $\quad$ http://apps.who.int/iris/bitstream/handle/10665/260202/9789241513647eng.pdf?sequence $=1$

World Health Organization (WHO). (2020). Rolling updates on coronavirus disease (Covid19). Https://www.who.int/emergencies/diseases/novel-coronavirus-2019/events-asthey-happen 